\title{
Research on Current Situation Investigation of Professional Ethics Current of Primary and Middle School Teachers
}

\author{
Shan $\mathrm{Hu}$ \\ School of Education and Sports, Bohai University, Jinzhou, 121013, China \\ guoxiaotian24@163.com
}

\begin{abstract}
Keywords: primary and middle school teachers; professional ethics; ethics idea; ethics behavior; current situation investigation
\end{abstract}

\begin{abstract}
On the basis of literature analysis and interviews with teachers, conceived the two dimensions of professional ethics for primary and middle school teachers: ethics idea and ethics behavior, and the building status of ethics idea and basic behavior for teachers as dimension compiled "professional ethics questionnaire for primary and middle school teachers". Investigate for 208 primary and middle school teachers in the questionnaire. The results show that: primary and middle school teachers universally have a correct understanding for the significance of ethics, existed correct ethics idea; but some teachers have the contradiction in the moral identity and moral fulfillment, knowledge and behavior have double standard and ethical behavior exist deviation, the problem behavior always occurs; regulating professional ethical behavior can become the entry point of improving professional ethics level for teacher.
\end{abstract}

\section{Introduction}

In the 21 st century, according to teachers' role characteristics, professional characteristics and the characteristics of teacher labor put forward higher requirements for teachers' literacy. Teachers should have the literacy including ethics cultivation, cultural cultivation, professionalism and psychological qualities. Among them, ethics cultivation is teacher-centered, the moral is first, especially primary and middle school teachers must have good moral character.

Teachers' professional ethics is the sum of the code of conduct and the necessary moral which should be followed by the person engaged in the teaching profession and is the specific performance of general social ethics in the teaching profession. Due to the special nature of the teaching profession, teachers' professional ethics not only affects the growth of China's new generation, but also is the model of professional ethics for other social industry. As the core component of teacher quality, teachers' professional ethics has become the focus of attention for education reform and teachers' construction in our country [1].

With the development of society, teachers' professional ethics is constantly given new meaning. Since the founding country, based on the requirements of the times, our primary and middle schools teachers' professional ethics changes severally, from October 1984 the Ministry of Education and the National Education Union issued "primary and middle teachers' professional ethics requirements (draft)" in the six provisions to 1991 in August by the National Board of Education and the National Education Union jointly issued the "teacher' professional ethics" six requirements to September 1997 revised eight states, and then in 2008 the Ministry of Education revised "teachers' professional morality norms ", namely teachers should be patriotic and law-abiding, dedication, care for students, teaching, a teacher and lifelong learning [2]. Ethics is a division of legislation, so-called "Road stored, the division of the deposit." Since the 1980s, the several amendments of "standard" are based on that ethics is a basic requirement for teachers, are the basic professional ethics teachers must have in working education.

The main purpose of this study is to survey and analyze the professional ethics current situation for after the implementation of new "standard", to provide factual basis to better promote the implementation of "standard" and improve the direction and effectiveness of ethics construction. Study used survey methods, combined with four teachers' professional ethics relations involved in 
the "standard" newly issued, namely teachers and education, teachers and students, teachers and teachers, teachers and parents, conceived two dimensions about primary and middle schools teachers' professional ethics: ethics idea and ethics behavior, and the building status of ethics idea and basic behavior for teachers as dimension compiled questionnaire.

\section{Questionnaire Establishment}

The establishment of self-made "professional ethics questionnaire for primary and middle school teachers" used institute need the following steps.

Firstly, literatures search. Determining teachers' professional ethics constitute by two factors that is the ethics idea and ethics behavior.

Secondly, interviews and open questionnaires. On the basis of referencing the relevant data specifically analysis professional characteristics for teacher, construct the semi-structured questionnaire for 10 primary and middle school teachers and interview on the theme of professional ethics for primary and middle school teachers, collect the item of describing the professional ethics standard, conceived two dimensions for primary and middle school teachers' professional ethics: ethics idea and ethics behavior (in which, 6 projects reflecting teachers' professional ethics, 8 projects reflecting the ethics behavior).

Thirdly, assess, modify the initial questionnaire. Invited the primary and middle school teachers to evaluate for initial questionnaire, modify the conformance of questionnaire content with ethics situation and the understanding of questionnaire. Further requests the psychology expert and experienced teachers test the adaptability of project and the validity of questionnaire.

Fourth, modify and measurement.

\section{Research Result}

Choose 228 teachers in the primary and middle school school located Shenyang, Dalian, Chaoyang, Kaiyuan, Taian, Wafangdian, Yingkou, Liaoyang, Kazuo, Jinzhou, Huludao, Fuxin, Panjin, Anshan, Zhuanghe, Fushun, Dandong, Donggang, Montenegro, Lingyuan Tieling, Benxi in Liaoning Province total of as subjects, and finally actually gets 208 valid questionnaires (with 91.2\% efficiency). The results are shown in Table 1. 
Table 1. Present situation of professional ethics for primary and middle school teachers

\begin{tabular}{c|l|c|c}
\hline No & \multicolumn{1}{|c|}{ Item } & Yes & No \\
\hline 1 & $\begin{array}{l}\text { I am generally satisfied with the current situation of professional ethics for primary and } \\
\text { middle school teacher. }\end{array}$ & 81.3 & 18.8 \\
\hline 2 & \begin{tabular}{l|l} 
I think morality is more important than knowledge level for primary and middle school \\
teacher.
\end{tabular} & 98.6 & 1.4 \\
\hline 3 & I believe that learning or training related to teachers' professional ethics is necessary. & 97.6 & 2.4 \\
\hline 4 & $\begin{array}{l}\text { I think teachers should strictly request personal demeanor. } \\
\text { I think the teacher should be responsible, carefully preparing classes, correcting homework } \\
\text { and tutoring students. }\end{array}$ & 100 & 0 \\
\hline 6 & $\begin{array}{l}\text { I had dragged lessons or tone string class phenomenon. } \\
\text { I had received a cell phone, send the information, and look at newspapers phenomenon in } \\
\text { the classroom. }\end{array}$ & 1.4 \\
\hline 8 & $\begin{array}{l}\text { I asked students to purchase periodical data, teaching tool, or the behavior for other } \\
\text { commodities. }\end{array}$ & 17.3 & 82.7 \\
\hline 9 & $\begin{array}{l}\text { I think students should be treated equally. } \\
10\end{array}$ & $\begin{array}{l}\text { I agree that the students made mistakes should be corporal punishment or corporal } \\
\text { punishment in disguised form. }\end{array}$ & 91.3 \\
\hline 11 & $\begin{array}{l}\text { I had received a gift from students or parents of students. } \\
\text { II had occurred contradiction with student's parents because student. }\end{array}$ & 100 & 0 \\
\hline 12 & $\begin{array}{l}\text { I chatted with the study and living conditions in school in the form of visiting home or } \\
\text { telephone for children. }\end{array}$ & 9.7 & 92.3 \\
\hline 14 & I asked their parents because the children make mistakes. & 17.3 & 82.7 \\
\hline
\end{tabular}

\section{Result and Discussions}

According to survey results, the current primary and middle school teachers generally has a good acceptance on the "standard" and has a correct understanding for the significance of ethics, there is no right of ethics idea. But at the same time also we found some problems teachers fulfill "standard" requirement existing in the process, analyze the main reason is there is a gap between the level of requirements "standard" set forth in the operability and practice. Specific performance is shown the following three aspects:

\section{(1) Primary and middle school teachers generally have a clear understanding for the ethics} idea

Ethics idea is the deep structure of ethics is based on the premise of ethics behavior and thinking, teachers' intrinsic quality of professional ethics, for ethics behavior plays a leading role. Survey results show that primary and middle school teachers generally to have a clear understanding of ethics idea. The vast majority of primary and middle school teachers have a relatively clear right and wrong, and the current status of school teachers of ethics was basically satisfied [3].

Professional ethics majority idea is good for expanded primary and middle school teachers, 81.3 percent of primary and middle school teachers on the current status of professional ethics was basically satisfied, but dissatisfied with the status of professional ethics of only $18.8 \%$. Mainly in: school teachers generally believe that moral training of teachers is more important than knowledge level, teachers hold this view accounted for 98.6\%; believe teachers' professional ethics aspects related to learning or training necessary to account for $97.6 \%$; All primary and middle school teachers think teachers should be personal demeanor stringent requirements; think teachers respond responsible, serious preparation classes, correcting homework, tutoring students accounted for 98.6\%; all primary and middle school teachers believe that students should be treated equal equity.

Of course, the survey results also show that there is still very little influenced in part due to primary and middle school teachers extreme individualism, pragmatism and other utilitarian ideas, their poor sense of ethics, there are few teachers face diverse, pluralistic, changing Social Trends lack of discernment, some teachers even had a radical the concept of. Therefore, strengthen ethics 
training, adhere to ethics and teacher can try, which is the core construction of teachers. The current ethics idea school teachers need to be further improved.

On the one hand, the moral construction, the state promulgated the education laws and regulations are based, system management is guaranteed. Construction administrative departments of education should be strengthened establishes a new system, strict reward and punishment system and other steel [4]. Schools should strengthen the system, to exercise ethics norms, rules and regulations to improve moral construction, building long-term mechanism to establish ethics, ethics construction to build a scientific and effective system of monitoring and evaluation work, as an annual assessment of the performance of the ethics teacher, Appointment and awards, etc. appraised the important basis. On ethics underperforming teachers should promptly admonished by exhortation fails to amend teacher, to be dealt with severely; for serious misconduct, adverse effects should be withdrawn and be dismissed teacher qualification.

On the other hand, expand ethics training in ways to make primary and middle school teachers of ethics increased from perceptual to rational knowledge. Consciously training ethics emotion and strengthening its ethics idea. The formation of new educational concepts for teacher requires continually enhance learning educational theory, a profound understanding of education policies, and consciously reflect on education, enhance the sense of self-education.

Again, noble morality is to strengthen self-education gradually formed, should strengthen self-discipline for teachers, and cultivate self, self-training and other aspects of educational activities. In ethics construction using a variety of external incentives moderately stimulates teachers and stimulate their moral motivation, converts the ethics educational process into individual behavior.

(2) Professional ethical behavior exist deviation for some teachers, the problem behavior always occurs

Ethics problem behavior, refers to the number of teachers do not meet the ethical behavior required of teachers often generated. Teachers will lead to problem behavior management and educational activities of daily student bias and fault. While in primary and middle school teachers generally have a clear understanding of the concept of ethics through survey also found that some teachers are difficult pursuits in action, still there is a deviation of ethical behavior, moral issues when acts have occurred. In the aspect of ethics idea and ethics behavior showed conflicting and uncoordinated phenomenon.

The survey found that $49.5 \%$ of teachers have had dragged lessons or tone string class phenomenon; $17.3 \%$ of teachers in the classroom had received a cell phone, send the information, reading newspapers phenomenon; $8.7 \%$ of teachers have had students buy newspapers information and supplementary appliances or behavior of other commodities; $7.7 \%$ of teachers had corporal punishment or disguised corporal punishment on students of the phenomenon; $17.3 \%$ of teachers had received the student or parents of gifts; $19.7 \%$ of teachers because of the sake of the students and parents There have been contradictory; $49.5 \%$ of teachers because children make mistakes please their parents; $96.2 \%$ of teachers in home visits or telephone once talked to children in school learning or life situation.

The presence of some teachers' deviation ethical behavior, moral problem behavior occurs when there are many causes. On the one hand, the problem behavior is often triggered by erroneous teachers' philosophy. Education is duty-bound responsibility for teacher. However, many teachers in the exercise of discipline responsibility, legal consciousness of casual indifference, discipline methods. Some teachers still hold the traditional concepts of education that teachers for students with indisputable authority, students unconditional obedience teacher is justified, this inequality of teachers and outlook, will inevitably lead to tyranny in the management of teachers, often teacher-student relationship is likely to cause tension, or even hostility and conflict between teachers and students, which led to daily management and educational activities of students deviations and mistakes. This understanding of education and management under the guidance of some fault of student attitudes and behaviors that lead to excesses are inevitable. The main purpose of discipline should be consistent with the aims of education, education is to stimulate students' 
potential to the full development of students, if teachers due to the use of discipline or undue influence students' potential harm to the physical and mental development of students, it is a violation of the aims of education; on the other hand, "standard" of professional ethics of teachers to make the relevant provisions, but did not formulate relevant rules on teachers' professional ethical conduct, between the requirements specification and practice in the proposed operability the gap between its own scientific and operational deficiencies, the necessary measures to educate teachers' behavior would not achieve the role of norms and constraints, and this is precisely the norm, which restricts teachers' professional ethics behavior.

\section{(3) Regulating professional ethical behavior can become the entry point of improving professional ethics level for teacher}

Primary and middle school teachers' ethics generally have a clear understanding of the concept of, but it is difficult Pursuits in action. In general, the ideal state about teachers' professional ethics is to achieve harmonious development of ethics idea and ethical behavior. However, in the current school education, teacher's positive moral values, does not necessarily bring about positive ethical behavior. Survey results reflect the ethics idea on the positive side for primary and middle school teachers, at the same time, some school teachers there is a contradiction in the moral identity and moral practice of on-line double standards known. For example the survey showed that $98.6 \%$ of teachers think that teachers respond responsible, careful preparation classes; but at work, $49.5 \%$ of the teachers have had dragged lessons or tone string class phenomenon [5].

Any education teachers teaching behavior cannot be contrary to legal norms and ethics education. Reasonable teacher education and teaching behavior depends whether adopted educational method, means and measures are reasonable. On the one hand, schools need to strengthen the teaching management and standardize teacher behavior. Teachers' awareness of the law is indifferent breeding hotbed of problem behaviors teachers, classroom teachers to eliminate the problem behavior occurs fundamentally, we must teach the rule of law, in strict accordance with the requirements of national law and the regulations of conducting educational activities. In the management process must develop a scientific system to regulate the behavior of teachers, schools can establish various rules and regulations of the relevant laws and regulations specific to implement the school's management among teachers in order to regulate behavior, improve teacher quality. As of now many schools have developed a "classroom teaching Taboo", "Code of classroom teaching," "classroom teaching ten are not allowed" and other rules and regulations. So that teachers in the constraints of the system among the teachers in the system management to clarify the directionality of behavior, to overcome the arbitrariness of teacher behavior [6].

On the other hand, practice and ethical conduct demonstration. Strengthen ethics training; teachers should give full play an exemplary behavior and ethical role model. Teaching by example is teaching without words, all acts of teachers in front of students of all educational activities take place, will have a positive or negative impact. Therefore, teachers should pay special attention to their behavior; give full play to the exemplary role of behavior. Teachers should re-trivial, arrested a small ceremony, strengthen self-cultivation, set an example, to set an example for students.

Finally, must strengthen monitoring mechanisms for teacher behavior. Should promptly found, help and corrected teachers with problem behavior, in serious cases to be made in accordance with the relevant provisions of punishment, not tolerated. On the basis of the initial knowing combination for cultivating teachers' ethics, to achieve the integrate unity between "know" and "line", in order to continuously improve the realm of ethics.

\section{Conclusion}

It can be seen from the above analysis, even though ethics idea generally is positive for primary and middle school teachers, the ethical behaviors still occur. Thus, in the daily teaching activities, strengthening the teaching management, standardize teachers' education behavior can be used as an entry point to improve teachers' ethics. Schools can establish various rules and regulations to embody the requirement of relevant laws and regulations and to implement the school's management. Therefore, recommended that the authorities should pay attention to further research 
and develop ethics norms implementation details with distinct levels, specific requires, clear and feasible for teachers; establish the perform assessment system; strengthen supervision and security system construction; seek effective practice ways and means to effectively improve teachers' professional ethical standards. Between the requirements of professional ethics for teachers and practicing still exist a big gap, strengthening teachers' professional ethics construction and enhancing the level of teachers' professional ethics cultivation have a long way to go.

\section{References}

[1] J. L. Shen, J. X. Zhao, "The reality of primary and secondary school teachers' professional ethics thinking," Journal of Beijing normal university (social science edition), vol. 42, no. 1, pp. 48-55, 2006.

[2] Baidu Encyclopedia, "eachers' professional ethics in primary and middle school," http://baike.baidu.com/link?url=LS6XSU -G_xS6ArWO, 2015-9-6.

[3] H. R. Shao, "Investigation and research on the teachers' morality consciousness of normal university students," Henan academy of social sciences, vol. 19, no. 5, pp. 162-165, 2011.

[4] X. G. Xu, S. Y. Wang, "On improving teachers' morality in primary and middle school," Primary and middle school teacher training, vol. 27, no. 1, pp. 54-56, 2004.

[5] N. B. Zhu, "Investigation and research on the current situation of teachers' professional ethics in primary and middle schools," Education science, vol. 25, no. 6, pp. 37-41, 2009.

[6] Z. H. Li, "Teacher classroom problem behavior and its prevention strategy," Higher education research, vol. 28, no. 11, pp. 44-48, 2007. 